Conflict and Compliance 
PENNSYLVANIA STUDIES IN HUMAN RIGHTS Bert B. Lockwood, Jr., Series Editor

A complete list of books in the series is available from the publisher. 


\section{Conflict and Compliance}

\section{State Responses to International}

Human Rights Pressure

SONIA GARDENAS

$\overline{\text { PENN }}$

University of Pennsylvania Press

Philadelphia 
Copyright $@ 2007$ University of Pennsylvania Press

All rights reserved

Printed in the United States of America on acid-free paper

$\begin{array}{llllllllll}10 & 9 & 8 & 7 & 6 & 5 & 4 & 3 & 2 & 1\end{array}$

Published by

University of Pennsylvania Press

Philadelphia, Pennsylvania 19104-4112

Library of Congress Cataloging-in-Publication Data

Cardenas, Sonia.

Conflict and compliance : state responses to international human rights pressure / Sonia Cardenas.

p. $\mathrm{cm}$. - (Pennsylvania studies in human rights)

Includes bibliographical references and index.

ISBN-13: 978-0-8122-3999-7

ISBN-10: 0-8122-3999-7 (cloth : alk. paper)

1. Human rights. 2. International relations. I. Title. II. Series.

JC571.C28 2007

323-dc22

2006051454 
For Andy and Alex 
This page intentionally left blank 